Immunology Department,

Animal Health Research Institute, Dokki, Egypt.

\title{
STUDIES ON THE STIMULATION OF DATES ON RAT IMMUNE RESPONSE AND THEIR EFFECTS ON SOME BACTERIAL STRAINS
}

(With 8 Tables)

\section{By}

NAGWA A. SAID; M. HASHAD*; A.A. NADA;

A. AL-QAEAWY ** and SAHER A. GALAL

* Dept. of Microbiology, Faculty of Vet. Med., Cairo University.

** Dept. of Vet. Med. Fac. of Agriculture and Vet. Med., king Saud Univ.,

Al- Qassim, Saudi Arabia.

(Received at 20/12/2006)

دراسة التمر كمحفز مناعي على الاستجابة المناعية فى الفئران وتأثيراته على أنواع مختلفة من البكتريا

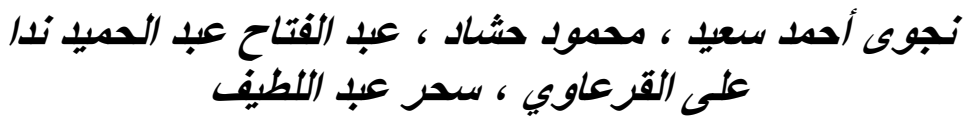

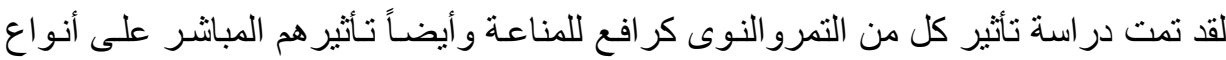

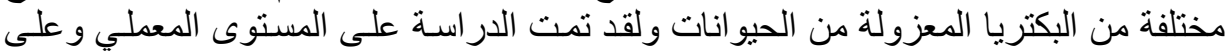

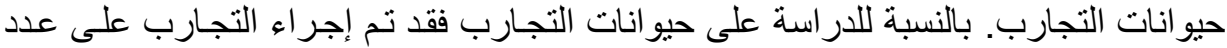

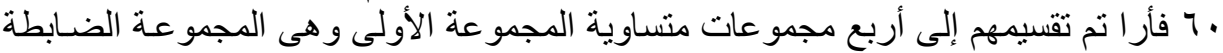

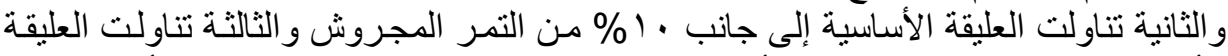

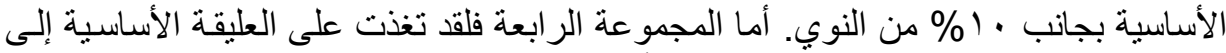

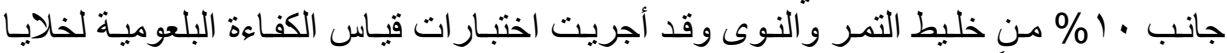

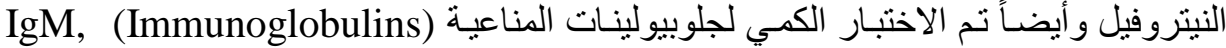

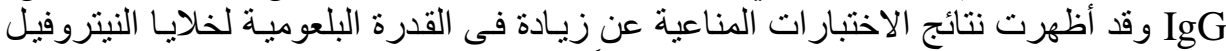

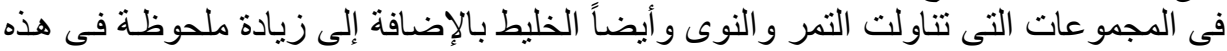

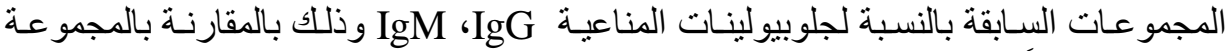

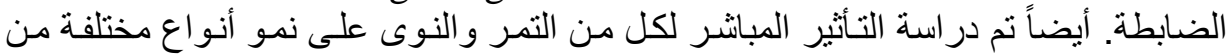

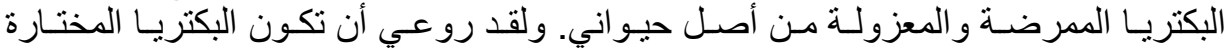

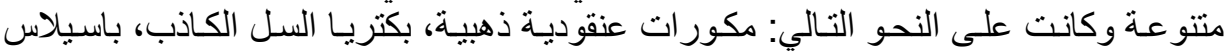

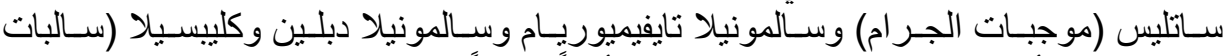

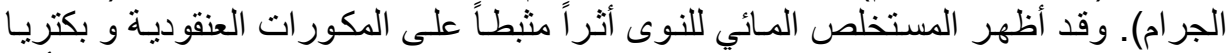

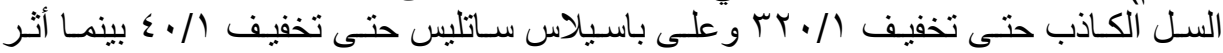

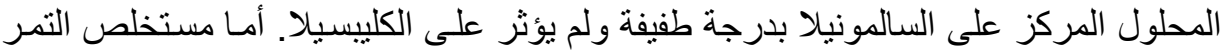




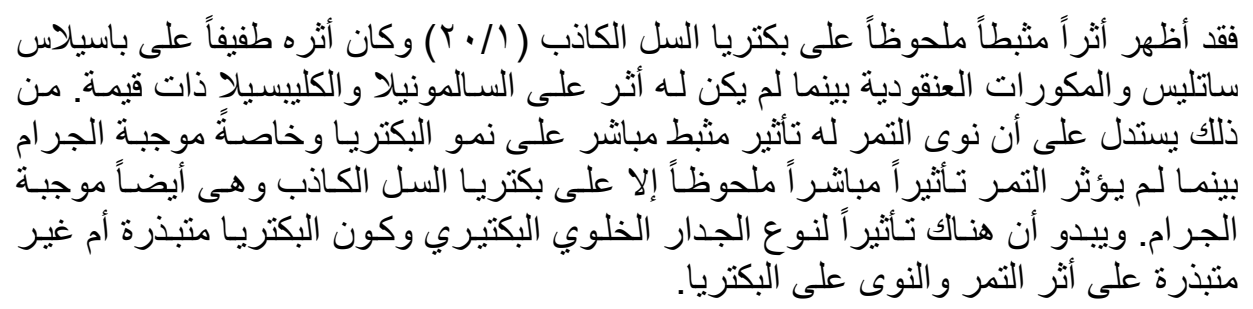

\section{SUMMARY}

To better understand, the effect of dates and pits as immuno stimulant agent and their effects on different species of pathogenic bacteria of animal origin, were investigated In Vivo and In Vitro. In Vivo experimental sixty Albino rats were divided into four equal groups, group one as control, group two fed a basal diet supplemented with $10 \%$ minced dates, group three fed a basal diet supplemented with $10 \%$ pits, group four fed a basal diet supplemented with $10 \%$ mixed minced dates and pits. Phagocytic percent and phagoaytic index were assessed. Also, quantitative detection of immunoglobulins (IgG-IgM) were detected. Immunological investigations revealed significant increase in phagocytic activity of neutrophils in groups treated with dates, pits and mixed compared with control. Also, the same treated groups exhibited (Hyperimmuno-globuinaemia) significant increase in values of immunoglobulins (IgG and IgM) compared with control animals. Also, the direct effects of dates and pits, on different species of pathogenic bacteria of animal origin, were investigated. Test bacteria were selected to represent different species. The tested bacteria included Staphylococcus aureus, Corynebacterium pseudotuberculosis and Bacillus subtilis (Gram-positive) and Salmonella typhimurium, Salmonella dublin and Klebsiella species (Gram-negative). The water extract of pits showed clear inhibition for both Staphylococcus aureus and Corynebacterium pseudotuberculosis until 1/320 dilution. Bacillus subtilis was also inhibited but up to higher concentration (1/40). The effect of concentrated extract was minute on salmobnellae while no effect was detected with klebsiella. On the other hand, water extract of dates showed a detectable inhibitory effect on Corynebacterium pseudotuberculosis until the concentration 1/20. The effect of date extract was minute on Staphylococcus aureus and Bacillus subtilis while no effect was observed against the Gram-negative species. From these results, it can be concluded that date seeds (pits) have a direct inhibitory effect on Gram-positive bacteria while dates had affected 
Corynebacterium pseudotuberculosis only which is also Gram-positive bacterium. It looks like that it affects the bacterial cell wall composition.

Key words: Immunology, phagocytic activity, dates, rats.

\section{INTRODUCTION}

Dates, the fruit of the date palm (phoenix dactylifera), represents an important highly nutritive source for human and animals. This has been attributed to the constituents of the dates. Of these constituents, sugars that are considered the most important source of energy Additionally, dates contain considerable ratios of vitamins (A and B complex), minerals, proteins and fibres (Saway and Miski, 1983; Eromosele et al., 1991; Alshahib and marshall, 2003).

It has been reported that consumption of dates by human beings has a lot of healthy benefits, it improves vision and hearing nerves, growth rate of children and blood vessel capability. Also dates have been prescribed for athletics, pregnant women, heart problems and gastric ulcer, (Al Qarawi et al., 2005). Minerals in dates help in development of teeth and bones while fibers protect against enteritis and cancer (Mills et al., 1989; Ishurd et al., 2004).

Furthermore, some studies indicated that dates stimulate the immune system of human being (Puri et al., 2000). Not only date flesh but also the date pits have been found to be of high nutritive value that pits could compete cereals in formations of non traditional animal rations for different purposes (Alwash et al., 1982).

Concerning microbial pathogens, dates were described, in the public medicine for treatment of respiratory diseases of bacterial causes such as bronchitis and pneumonia. Also, dates showed antibiotic- like effects on some types of bacteria (Abdel salam, 1994).

In the present study, immunological effects of dates and pits were studied In Vivo using rat as model of experimental animals. Also, the direct effect of dates and pits on some pathogenic bacteria were studied. This was to evaluate probability of their applications as immunastimulant agents and in controls and prevention of certain bacterial diseases in human and animals. 


\section{MATERIALS and METHODS}

\section{Materials:}

\section{1- Experimental animals:}

A total of 60 male Albino rats weighing from 150 to $170 \mathrm{gm}$ were used. The rats were housed in plastic cages under good hygienic condtions and fed on balanced ration and water ad- libitum.

\section{Experimental Design: -}

Two experiments were carried out in the present study, the first In Vivo and the second in vitro.

Experiment (1): this experiment was conducted to evaluate the effect of dates and pits on the immune response on rats.

Sixty rats were divided into four groups (15 rats each).

Group 1: served as a control fed on a commercial basal diet.

Group 2: rats fed on a basal diet supplemented with $10 \%$ minced dates.

Group 3: rats fed on basel diet supplemented with $10 \%$ minced pits.

Group 4: rats fed a basal diet supplemented with $10 \%$ from minced mixed dates and pits.

Two blood samples were obtained from retroorbital venous plexus at 15, 30 and 45 days through the experiment. The first sample was collected into a plastic centrifuge tube containing heparin $20 \mathrm{I} . \mathrm{U} / \mathrm{ml}$ blood for measuring the phagocytic activity of neutroplils for cellmediated immune response assessment using Dextran, 5000,000 M.W, from Sigma according to the method described by Wilkinson (1981). The second sample of blood was taken into dry tube, serum was collected by centrifugation at 3000 r.p.m for 15 mintes for qualitative detection of serum immunoglobulins, IgG, IgM: Specific Rat Radial immunodifussion plates (The Binding site, BIND A RID, Birmingham, U.K.) were used to quantitate immunoglobulins (IgG and $\operatorname{IgM}$ ) in sera $\mathrm{mg} / \mathrm{ml}$ according to Mancini et al. (1965).

\section{(A) Dates and pits:}

Dried dats and pits were obtained from Egypt, Assuit type and minced into small pieces for addition to ration.

\section{(B) Dates and pits:}

Two hundred grams of semidried date flesh of the sokkary brand were minced into small pieces, exposed to ultraviolet for 4 hours, and soaked in sterile distilled water (1/5) for an overnight. Ground pits were treated similarly and both extracts were serially diluted two fold in sterile distilled water $(1 / 5,1 / 10$, until 1/2560). 


\section{Bacterial cultures:}

Staphylococcus aureus, Corynebacterium pseudotuberculosis, Bacillus subtilis Salmonella typhimurium, Salmonella dublin, and Klebsiella spp. were, separately, tested against each dilution of both date and pit extracts. With the exception of Bacillus subtilis, bacterial species represented isolates from clinically diseased animals (Table 1) and identified through standard bacteriologic methods (Quinn and Carter, 1994).

\section{Bacterial culture inoculates:}

Each bacterial isolate was cultivated onto brain heart infusion agar plates and incubated at $37^{\circ} \mathrm{C}$ for 24 hours. Few colonies were picked from each bacterial growth and transferred to a tube containing $3 \mathrm{ml}$ of Mueller-Hinton broth. The inoculated tubes were incubated at $37^{\circ} \mathrm{C}$ for few hours until a turbidity matched that of McFarland tube number 0.5 to be used in the micrbiological assays (Quinn and Carter, 1994).

\section{Bacteriological assays:}

\section{Diffusion method:}

Four plates of Mueller-Hinton agar were used for each bacterial species. The plates were evenly seeded with the bacterial inoculates using swabs emersed in the corresponding Mueller-Hinton broth cultures. The inoculated plates were allowed to dry at room temperature for 10 minutes. Five wells $(8 \mathrm{~mm}$ in diameter) were punched in each plate using a sterile cork borer. From each dilution of either date or pit extract, $100 \mu \mathrm{l}$ were delivered into a corresponding well of the inoculated Mueller-Hinton agar plates. The test plates were incubated at $35^{\circ} \mathrm{C}$ for 18 hours after which they were examined for bacterial growth inhibition around wells charged with date or pit diluted extract. Inhibition zone diameters were measured using a transparent ruler. (Stokes and Ridgway, 1987).

\section{Microdilution susceptibility assay:}

Both dates and pits were tested to detect the minimal concentration that can inhibit bacterial multiplication. This was carried out by using sterile 96-well microculture plates in which $50 \mu \mathrm{l}$ of either date or pit diluted extract were delivered into wells of corresponding columns (1-10). Equal volumes of each bacterial broth culture were delivered into wells of corresponding rows (A-F) to reach a bacterial concentration of $10^{5}$ bacterial cell/ $1 \mathrm{ml}$. Columns 10 and 11 as well as rows $\mathrm{G}$ and $\mathrm{H}$ were left as controls for bacteria and extracts, respectively. After mixing by gentle tapping, the inoculated plates were incubated at $35^{\circ} \mathrm{C}$ for 18 hours. After incubation, wells were checked for 
bacterial growth inhibition indicated by clearance of the mixture. The minimal inhibitory concentration was expressed as the highest dilution that could inhibit the bacterial growth (NCCLS Subcommittee, 1980).

\section{RESULTS}

Table 1: Phagocytic percentage and phagocytic index of rat neutrophils fed with $10 \%$ dates, pits and mixed at 15,30 and 45 days.

\begin{tabular}{|l|c|c|c|c|c|c|}
\hline \multicolumn{1}{|c|}{ Time } & \multicolumn{2}{c|}{15 days } & \multicolumn{2}{c|}{30 days } & \multicolumn{2}{c|}{45 days } \\
\hline $\begin{array}{l}\text { Group } \\
\text { Parameters }\end{array}$ & Phagocytic\% & Phago index & $\begin{array}{c}\text { Phago } \\
\%\end{array}$ & Phago index & $\begin{array}{c}\text { Phago } \\
\%\end{array}$ & Phago index \\
\hline Control & $47 \pm 0.91$ & $1.27 \pm 1.2$ & $49 \pm 1.2$ & $1.4 \pm 0.02$ & $49 \pm 2.4$ & $1.4 \pm 0.05$ \\
\hline Dates & $51 \pm 1.8$ & $1.3 \pm 0.02$ & $60 \pm 3.5 *$ & $1.8 \pm 0.02 * *$ & $65 \pm 1.7 * *$ & $1.9 \pm 0.08 * *$ \\
\hline Pits & $52 \pm 1.2$ & $1.01 \pm 0.03$ & $53 \pm 1.6 *$ & $1.7 \pm 0.01 *$ & $60 \pm 2.1 *$ & $1.8 \pm 0.06 *$ \\
\hline Mixed & $52 \pm 2.1$ & $1.3 \pm 0.10$ & $57 \pm 3.4 *$ & $1.8 \pm 0.05 * *$ & $63 \pm 2.1 * *$ & $1.9 \pm .07 * *$ \\
\hline
\end{tabular}

$* \mathrm{p}<0.05$. $* * \mathrm{p}<0.01$.

Table 2: Serum immmuno globulins $\mathrm{IgG}(\mathrm{mg} / \mathrm{ml})$ in sera of Albino rats fed with $10 \%$ dates, Pits and mixed at 15 days, 30 days \& 45 days.

$\operatorname{IgG}(\mathrm{mg} / \mathrm{ml})$

\begin{tabular}{|c|c|c|c|}
\hline \multicolumn{1}{|c|}{ Groups } & 15 days & 30 days & 45 days \\
\hline Time & & & \\
\hline Control & $10.9 \pm 0.08$ & $10.9 \pm 0.12$ & $10.9 \pm 0.12$ \\
\hline Dates & $11.7 \pm 0.4$ & $12.38 \pm 0.6^{*}$ & $12.4 \pm 0.6^{*}$ \\
\hline Pits & $14.5 \pm 0.3^{* *}$ & $14.9 \pm 0.2^{* *}$ & $14.9 \pm 0.2^{* *}$ \\
\hline Mixed & $13.6 \pm 0.4^{* *}$ & $14.2 \pm 0.09^{* *}$ & $14.42 \pm 0.09^{* *}$ \\
\hline
\end{tabular}

$* \mathrm{p}<0.05 . \quad * * \mathrm{p}<0.01$.

Table 3: Serum immunoglobulins $\operatorname{IgM}(\mathrm{mg} / \mathrm{ml})$ in sera of Albino rats fed with $10 \%$ dates, pits and mixed at 15, 30 and 45 days ( $\operatorname{IgM}(\mathrm{mg} / \mathrm{ml})$.

\begin{tabular}{|c|c|c|c|}
\hline Groups & 15 days & 30 days & 45 days \\
\hline Time & & & \\
\hline Control & $2.1 \pm 0.3$ & $2.2 \pm 0.06$ & $2.2 \pm 0.06$ \\
\hline Dates & $2.8 \pm 0.05^{* *}$ & $2.93 \pm 0.05^{* *}$ & $3.01 \pm 0.08^{* *}$ \\
\hline Pits & $2.95 \pm 0.03^{* *}$ & $2.96 \pm 0.07 * *$ & $3.04 \pm 0.07 * *$ \\
\hline Mixed & $2.97 \pm 0.06 * *$ & $2.97 \pm 0.05 * *$ & $3.05 \pm 0.06^{* *}$ \\
\hline
\end{tabular}

$* \mathrm{p}<0.05 . \quad * * \mathrm{p}<0.01$. 
Table 4: Sources of bacterial isolates tested in the study.

\begin{tabular}{|l|l|}
\hline \multicolumn{1}{|c|}{ Bacterial species } & \multicolumn{1}{c|}{ Source } \\
\hline Staphylococcus aureus & Abscess in a camel kidney \\
\hline Corynebacterium pseudotuberculosis & Lymph node abscess in a sheep \\
\hline Bacillus subtilis & ATCC 6633 \\
\hline Salmonella typhimurium & Cattle \\
\hline Salmonella dublin & Cattle \\
\hline Klebsiella spp. & Chicken \\
\hline
\end{tabular}

Table 5: Effects of different dilutions of pit-water-extract on bacterial growth In Vitro.

\begin{tabular}{|l|c|c|c|c|c|c|c|c|c|c|}
\hline & $1 / 5$ & $1 / 10$ & $1 / 20$ & $1 / 40$ & $1 / 80$ & $1 / 160$ & $1 / 320$ & $1 / 640$ & $1 / 1280$ & $1 / 2560$ \\
\hline Staphylococcus aureus & + & + & + & + & + & + & + & - & - & - \\
$\begin{array}{l}\text { Corynebacterium } \\
\text { pseudotuberculosis } \\
\text { Bacillus subtilis }\end{array}$ & + & + & + & + & + & + & + & - & - & - \\
$\begin{array}{l}\text { Salmonella } \\
\text { typhimurium }\end{array}$ & + & + & + & + & + & - & - & - & - & - \\
$\begin{array}{l}\text { Salmonella dublin } \\
\text { Klebsiella spp. }\end{array}$ & - & - & - & - & - & - & - & - & - & - \\
\hline
\end{tabular}

$+:$ Inhibition of the bacterial growth.

- : No inhibition of the bacterial growth.

Table 6: Effects of different dilutions of date-water-extract on bacterial growth in vitro.

\begin{tabular}{|l|c|c|c|c|c|c|c|c|c|c|}
\hline & $1 / 5$ & $1 / 10$ & $1 / 20$ & $1 / 40$ & $1 / 80$ & $1 / 160$ & $1 / 320$ & $1 / 640$ & $1 / 1280$ & $1 / 2560$ \\
\hline Staphylococcus aureus & - & - & - & - & - & - & - & - & - & - \\
$\begin{array}{l}\text { Corynebacterium } \\
\text { pseudotuberculosis } \\
\text { Bacillus subtilis }\end{array}$ & + & + & + & - & - & - & - & - & - & - \\
Salmonella dublin & - & - & - & - & - & - & - & - & - & - \\
Salmonella typhimurium & - & - & - & - & - & - & - & - & - & - \\
Klebsiella spp. & - & - & - & - & - & - & - & - & - & - \\
\hline
\end{tabular}

$+:$ Inhibition of the bacterial growth.

- : No inhibition of the bacterial growth. 
Table 7: Zone diameters of inhibition produced by pit-water-extract on different bacterial isolates.

\begin{tabular}{|l|c|c|c|c|c|c|c|}
\hline & $1 / 5$ & $1 / 10$ & $1 / 20$ & $1 / 40$ & $1 / 80$ & $1 / 160$ & $1 / 320$ \\
\hline Staphylococcus aureus & $17^{*}$ & 16 & 14 & 12 & 11 & 10 & 9 \\
\hline Corynebacterium pseudotuberculosis & 18 & 16 & 15 & 13 & 12 & 11 & 10 \\
\hline Bacillus subtilis & 13 & 12 & 11 & 9 & 9 & $8^{* *}$ & 8 \\
\hline Salmonella typhimurium & 8 & 8 & 8 & 8 & 8 & 8 & 8 \\
\hline Salmonella dublin & 8 & 8 & 8 & 8 & 8 & 8 & 8 \\
\hline Klebsiella spp. & 8 & 8 & 8 & 8 & 8 & 8 & 8 \\
\hline
\end{tabular}

* : Diameters are expressed in millimeters ( $\mathrm{mm})$.

** : no inhibition as the well diameter was $8 \mathrm{~mm}$.

Table 8: Zone diameters of inhibition produced by date-water-extract on different bacterial isolates.

\begin{tabular}{|l|c|c|c|c|c|c|c|}
\hline & $1 / 5$ & $1 / 10$ & $1 / 20$ & $1 / 40$ & $1 / 80$ & $1 / 160$ & $1 / 320$ \\
\hline Staphylococcus aureus & 8 & 8 & $8^{* *}$ & 8 & 8 & 8 & 8 \\
\hline Corynebacterium pseudotuberculosis & $14^{*}$ & 12 & 11 & 11 & 8 & 8 & 8 \\
\hline Bacillus subtilis & 8 & 8 & 8 & 8 & 8 & 8 & 8 \\
\hline Salmonella typhimurium & 8 & 8 & 8 & 8 & 8 & 8 & 8 \\
\hline Salmonella dublin & 8 & 8 & 8 & 8 & 8 & 8 & 8 \\
\hline Klebsiella spp. & 8 & 8 & 8 & 8 & 8 & 8 & 8 \\
\hline
\end{tabular}

*: Diameters are expressed in millimeters $(\mathrm{mm})$.

** : no inhibition as the well diameter was $8 \mathrm{~mm}$.

\section{DISCUSSION}

Dates have been evaluated for their nutritive and medical values by many authors (Booij and Piombo, 1992; Abdel Salam 1994; Hussein et al., 1998; Al-Dabeeb, 2005). Concerning pits, a lot of successful studies have been mentioned about their use as essential element in animal rations (Alwash et al., 1982). However a little attention has been paid to their effects on immune responses as well as direct antibacterial effect therefore, this study was planned to test date flesh and pits as immunostimulant agent In Vivo, in addition to their direct effect against different species of bacteria.

Phagocytic activity of neutrophils as shown in Table (1) revealed a significant increase in phogocytic percentage and phagocytic index in all treated groups with dates, pits and mixed (dates \& pits) compared 
with control animal at 30 and 45 days. Also, value of immunogloblins IgG and IgM are presented in Table (2) and Table (3). The tables show that significant increase in $\operatorname{IgG}$ and $\operatorname{IgM}$ in all treated groups with dates, pits and their mixture compared with control animals during experiment, Highly significant enhancement of immunoglobulins was more prominent in all treated groups (dates, pits and their mixture) at 30 and 45 days.

These results indicate significant immunostimu-latory activity of dates and pits, which agree with the results of Puri et al. (2000) who recorded an enhancement of macrophage activation and increased in haemagglutination antibody titres as well as plaque -forming cell (PFC) counts in mice orally administered date extract. The immunostimulatary activity of dates may be attributed to presence of $\beta$-D-glucan in date flesh. Ishurd et al. (2002) isolated B-D-glucan from the fruit of dates. B-D-glucan is an important candidate molecule of biological response modifier implicated in cancer, it can be obtained from other sources such as yeast, fungi, bacteria and plants. Similar results have been reported by Tokunaka et al. (2000) who mentioned that B-D-glucan has a higher biological effect in activation of alternative pathway of complement, induce interleukin-6-synthesis of macrophage In Vitro, and act as adjuvant effect on antibody production.

Furthermore our results agree with Al.shahib and Marsall (2003) who found that dates contain carbolydrate, fat, proteins, vitamins, fiber and at least 15 minerals, including selenium which play an important role in immune function and prevent cancer. Concerning pits there is no available data explaination about their immunological effects. However, a lot of successful studies have been mentioned about their use as essential element in the animal rations. Al washi et al. (1982) and Hussein et al. (1998) observed significant increase in body weight and improved feed utilization in chickens.

We elucidate the effect of dates and pits that stimulate the humoral and cellular immume response, immunoreactive and immunostimulant action, through Bcells, T-helper /inducer cell $\left(\mathrm{CD}_{4}\right.$ helper and $\mathrm{CD}_{8}$ ), T- cells receptor for major histocompatibiliy complex (MHC) molecule that mutate and regulate expression of immunoglobulins gene (Tizard, 1995).

Also, Ali et al. (1999) noticed high increase in body weight, plasma testosterone and improved feed utilization in male rats fed date pits at concentration that immunostimulatory activity of pits might be attributed to its constituent that have been already analyzed. 
The tested bacteria represented different Gram positive and Gram negative species (Table 4). With the diffusion method, it was found that the effect of date flesh extract was not inhibitory for the tested bacterial isolates except Corynebacterium pseudotuberculosis that was inhibited with high concentrations (first 2 wells). This effect can be attributed to the high sugar concentration of the extract as the effect disappeared with the dilution $1 / 20$. This was reported in previous studies in which it was mentined that Vibrio cholera was destroyed within 16 days after its mixing with dates (King, et al., 1968). In such experiments, the antibacterial effect of dates was attributed to the high sugar contents which can destroy bacterial cells through the osmotic imbalance and plasmolysis. Eventhough, the inhibition zone diameters around the first two wells of Corynebacterium pseudotuberculosis plate were not so wide to be considered. In contrast, the other tested bacterial species did not show any inhibition with either concentrated or diluted date flesh extract (Table 6). This is supported, to a large extent, with the success of many other studies in isolation of different bacterial and fungal species from black dates (Mikky \& Yanezo 1997). Thus, to fight pathogenic microorganisms, it can be suggested that maximum benefits can be obtained from date flesh through its indirect effect as immunostimulant. This is in addition to the well known role of consumable dates in the general health condition and fitness of the consumers.

Concerning pits, it was very interesting to detect strong inhibitory effects of pit-extract (until dilution 1/320) on both Staphylococcus aureus and Corynebacterium pseudotuberculosis (Table 5). Also, there was an inhibitory effect but to a lower extent (until dilution of 1/40) on Bacillus subtilis. On the other hand, no inhibitory effects were detected on Salmonella and Klebsiella species.

It can be, causiously, suggested that water extract of pits selectively affect Gram positive bacteria as the three inhibited species were Gram positive and the three unaffected ones are Gram negative. It is difficult to explain this finding, but it can be speculated that the bacterial cell wall composition has something to do with this interaction. In other words, the active principle(s) of pits inhibit the Gram positive bacteria through its effect on the cell wall formation. How this can happen, it can be through one of the pit constituents that have been already analyzed such as chlorine, sulpher or tannins (Booij \& Piombo, 1992). Otherwise, the active principle might be something else beyond the capabilities of the analytical methods. This is not unlogic because some antibiotics such as penicillin affect only Gram positive bacteria by 
inhibiting their cell wall formation. This means that the water-soluble antibacterial active principle (s) of the pits might have a penicillin-like effect. Absence of the inhibitory effect of pit-water extract on Gram negative bacteria tested in this study may reflect absence of the susceptible target in their cell walls (Table 7).

The results of the microdilution susceptibility assays were in agreement with those of the diffusion assays as bacterial growth was indicated by turbidity after the pit extract dilutions of 1/320,1/320 and 1/40 with Staphylococcus aureus, Corynebacterium pseudotuberculosis and Bacillus subtilis, respectively.

Conclusively, in addition to its use in ration formulation, date pit flour can be used for direct therapeutic purposes against diseases caused by Corynebacterium pseudotuberculosis and Staphylococcus aureus at this situation. The first species has been known for its role in many animal diseases as caseous lymphadenitis in sheep and goats. The second species is a well known pyogenic organism in both man and animals in addition to the human food poisoning (Hirsh and Zee, 1999; Quinn \& Carter 1994). It can be concluded that dates and pits may activate the humoral and cellular immune response.

However, this was the first trial in this concept and as enhancing results were obtained more research is recommended to answer many questions about dates and pits and the limits of their direct application in microbial disease therapy. Also, the real dilemma of pit-bacterial interaction is to be investigated as much as possible. This only can be achieved by cooperative studies between microbiologists, pharmacologists, chemists and clinicians.

\section{REFERENCES}

Abdel-Salam, N.A. (1994): Treatment with date-Tamr and -Rutab., Dar al-Taliah Press, Cairo.

AL-Dabeeb, S.N. (2005): Effect of feeding low quality date palm on growth performance and apparent digestion coefficients in fattening Najdi sheep. Small Ruminant Research 57(1)p:37-42.

Al-Qarawi, A.A.; Abde-Rahman, H.; Ali, B-H.; Mousa, H.M. and El-Mougy, S.A. (2005): The ameliorative effect of dates (phoenix dactyliferal) on ethanol induced gastric ulcer in rats. Journal of Ethnopharmacology 98(3) p: 313-317.

Al-Shahib, W. and Marshall, R.J. (2003): The fruit of date palm: its possible use as the best food for future? Int. J. Food. Sci. Nutri., 54 (4): 247-259. 
Ali, B.H.; Bashir, A.K. and Alhadrami, G. (1999): Reproductive hormonal status of rats treated with date pits. Food chemistry 66 (4): p.437-441.

Alwash, A.H.; Alkass, J.E. and Al-Haboby, A.H. (1982): The use of date stones for feeding and fattening ruminant animals World Review of Animal Productio, 18, 3.

Booij, I. and Piombo, G. (1992): Study of chemical composition of dates at different stages of maturity for the varietal characterization of different cultivars of date palm (Phoenix dactylifera, L.), Fruits Paris, 47 (6): 667-678.

Eromosele, I.C.; Eromosele, C.O. and Kuzhkzha, D.M. (1991): Evaluation of mineral elements and ascorbic acid contents in fruits of some wild plants. Plant-Foods for Human Nutrition, 41 (2): 151-154.

Hirsh, D.C. and Zee, Y.C. (1999): Veterinary Microbiology. Blackwell Science. (USA) p: 127-133

Hussein, A.S.; Alhadrami, G.A. and Khalil, Y.H. (1998): The use of dates and pits in broiler starter and finisher diets. Bioresource Technology 66(3): 219-223.

Ishurd, O.; Sun, C.; Xioo, P.; Ashour, A. and Pan, Y. (2002): A neutral B-D-glucan from dates of the date palm phoenix dactyl lifera L. Carbohydrate research $337 \mathrm{p}, 1225-1325$.

Ishurd, O.; Zgheel, F.; Kermagi, A.; Flefla, M. and Elmabruk, M. (2004): Antitumor activity of beta-D-glucan from Liby an dates. J. Mel. Foot 7(2): 252-255.

King, A.D.; Fields, R.K. and Boyle, F.P. (1968): Dried fruits have low microbial counts, Fd. Eng., 82-83.

Mancini, G.; Carbonora, A.O. and Hermans, J.F. (1965): Immunochemical qiantitation of antigens by single radial immunodiffusion. Immunochem, 2: 235-254.

Mikky, M.A. and Yanezo, A. (1997): Studies of microbial pollution and survival of some pathogenic bacteria on soft dates, in Procceding of the Symposium on "Business Fields in Date Palms and Related Industries": Sponsored by Council of Saudi Chambres (National Committee of Agriculture), Riyadh, Saudi Arabia, 2/12/1997. pp. 363-378 (in Arabic).

Mills, P.K.; Beeson, W.L.; Philips, R.L. and Fraser, G.E. (1989): Cohort study of diet, Life style, and prostate cancer in Adventist men. Cancer 64 (3): 598-604. 
NCCLS Subcommittee (1980): Antimicrobial Susceptibility Testing: Standard methods for dilution antimicrobial susceptibility tests for bacteria which grow aerobically. Proposed Standard: PSM7-July.

Puri, A.; Sahai, R.; Singh, K.L.; Saxena, R.P.; Jandon, J.S. and Saxena, K.C. (2000): Immunostimualnt activity of dry fruits and plant materials used in Indian traditional medical system for mothers after child birth and invalids, J. Ethnopharmacol., 71(1-2): 89-92.

Quinn, P.J. and Carter, M.E. (1994): Clinical Veterinary Microbiology, Mosby-Year Book Europe Limited.

Saway, W.N. and Miski, A.M. (1983): Physical and chemical characteristics of the major date varieties grown in Saudi Arabia. 1. Morphological measurements, proximate and mineral analysis, Dates Palm J., 2, 1-25.

Stokes, E.J. and Ridgway, G.L. (1987): Clinical Microbiology, $6^{\text {th }}$ edn, Edward Arnold, London, pp. 213 \& 216.

Tizard, I. (1995): "An Introduction to Veterinary Immunology" $4^{\text {th }}$ Ed., Sounders College Publishers, Harcourt Brance College Publishers.

Tokuunako, K.; Ohno, N.; Adachi, Y.; Tanaka, S.; Tamura, H. and Yadomae, T. (2000): Immunopharmacological activities of water soluble (1-3) B-D-glucan, CSBG from candida spp. Internation. Immunopharmacology 22 (5): 383-394.

Wilkinson, P.C. (1981): Techniques in Clinical Immunology $2^{\text {nd }}$ Ed., Blackwell Scientific Publication, London, pp. 287-288. 